\title{
Suğla Gölü Çevresi Prehistorik Dönem Yüzey Araştırması 2020 Yılı Çalışmaları
}

\author{
Dr. Ramazan Gündüz \\ Selçuk Üniversitesi, Edebiyat Fakültesi \\ Arkeoloji Bölümü \\ ramazangunduz@selcuk.edu.tr
}

Öz

Bu çalışma Suğla Gölü Çevresi Prehistorik Dönem Yüzey Araştırması kapsamında 2020 yılında çalışmaları yapılan alanların ve bu alanlarda ele geçen arkeolojik eserlerin bir ön değerlendirmesi niteliğindedir. 2020 yılı çalışmalarının öncelikli amacı bölgenin Prehistorik Dönemdeki durumunun anlaşılmasına katkı sağlamaktır. İlk aşamada bölgedeki yerleşmelerin tanımlanması, arkeolojik envanterinin çıkarılması ve güncel durumlarının tespit edilmesi planlanmıştır. Çalışmalardan elde edilen sonuçlar bölgenin Prehistorik Dönemleri hakkında yeni bilgiler edinmemize olanak sağlamıştır. Bu güne kadar Suğla Gölü çevresinde Neolitik ve/veya Kalkolitik Dönemde yalnız Suberde ve Gökhöyük Bağları Höyükte yerleşim olduğu biliniyorken 2020 yılı çalışmaları sonunda bölgede 6 yeni yerleşmede daha Geç Neolitik ve/veya Kalkolitik Dönem kültür kalıntıları tespit edilmiştir. Söz konusu yerleşmelerin en erken MÖ 7. binin sonu ve/veya 6.binyılın başına tarihlenebileceği öngörülmüştür. Bu yerleşmelerde tespit edilen buluntuların ortak özellikler göstermesinden bölge içerisinde homojen bir kültürün var olduğu anlaşılmıştır.

Anahtar Kelimeler: Prehistorya, Neolitik, Kalkolitik, Beyşehir-Suğla Havzası, Seydişehir.

\section{The Prehistoric Surface Survey of Sugla Lake Vicinity Studies in 2020}

\section{Abstract}

This study is a preliminary assessment of the areas in Suğla Lake Vicinity and the archaeological artifacts found in these areas in 2020 within the scope of the Prehistoric Period Survey of the Sugla Lake Vicinity. The primary purpose of the 2020 studies is to contribute to understanding the situation of the region in the Prehistoric Period.In the first stage, defining the settlements in the region, making an archaeological inventory and determining their current status were among our initial plans. The results have enabled us to obtain new information about Prehistoric Period of the vicinity. While it was already known earlier that there were only settlements in Suberde and Gökhöyük Bağları Höyügü in the Neolithic and/or Chalcolithic Period around Suğla Lake until recently, 6 new settlements of the Late Neolithic and/or Chalcolithic Period were identified in the region through the 2020 studies. It is predicted that these settlements may be dated to the end of the $7^{\text {th }}$ millennium $\mathrm{BC}$ and/or the beginning of the $6^{\text {th }}$ millennium BC. Since the findings show common features in these settlements, it is understood that there was a homogeneous culture in the region.

Keywords: Prehistory, Neolithic, Chalcolithic, Beyşehir-Suğla Basin, Seydişehir. 


\section{GİRIŞ}

Suğla Gölü havzası Konya il sınırları içerisinde, merkeze yaklaşık 100 km uzaklıktadır. Havza Beyşehir-Suğla oluğu olarak bilinen doğal çöküntü koridorunun doğu kısmını oluşturmaktadır. Batıda Beyşehir Gölü doğuda Suğla Gölü ve Çarşamba Vadisinin girişiyle sınırlanan havza güneydoğu kuzeybatı yönünde yaklaşı $150 \mathrm{~km}$ uzunluğa ve güney kuzey yönünde $50 \mathrm{~km}$ genişliğe sahiptir (Şekil 1). Coğrafi olarak Orta Toros Dağları'nın kuzeybatı bölümünde yer alan havzayı, batısından ve güney batısından Küpe Dağı, Kızıl Dağ ve Gidengelmez Dağları Kütlesi ile kuzeyden Alacadağ Kütlesi sınırlamaktadır (Şekil 2). Bu alanda Suğla Gölünün çekilmesiyle Orta Toros Dağları'nın kuzeybatı-güneydoğu ve kuzeydoğu-güneybatı yönlerinde geniş içbükey bir yay görünümünde ova oluşmuştur. Bu ova sınırları içerisinde günümüzde en batıda Seydişehir'den başlayarak Yalıhüyük ve Ahırlı ilçeleri yer almaktadır (Şekil 1).

Suğla Gölü Çevresi Prehistorik Dönem Yüzey Araştırması, 2020 yılında başlamıştır. Üç yıl devam etmesi planlanan yüzey Araştırması kapsamında yaklaşık $150 \mathrm{~km}$ uzunluğa sahip Beyşehir-Suğla havzasının tamamının taranması hedeflenmektedir. Araştırmalar öncelikli olarak Suğla Gölü çevresinde daha sonra Çarşamba Vadisi ve Beyşehir Gölü çevresinde devam ettirilecektir. Bu çalışmalar ile Suğla Gölü havzasının Prehistorik Dönemdeki durumunun anlaşılmasına katkı sağlanması amaçlanmaktadır. Ayrıca bu araştırmalar ile Beyşehir-Suğla havzasının, Orta Anadolu ve/veya Güneydoğu Anadolu'da ortaya çıan ya da gelişen kültürlerin Batı Anadolu'ya geçişte üstlenmiş olabileceği olası rol nedir sorusuna cevap aranacaktır. Cevaplanmayı bekleyen bir başka soru ise havzaya yaklaşık $80 \mathrm{~km}$ uzaklıkta, Neolitik Dönemin en gelişmiş yerleşim yerlerinden biri olan Çatalhöyük'ün havza içindeki yerleşmeler ile nasıl bir etkileşim içinde olduğudur. Bu ilk çalışma sezonunda hedefimiz Suğla Gölünün kuzeyindeki sahanın taranması, bu saha içindeki olası yerleşmelerin tespiti ve/veya tanımlanması, ele geçen arkeolojik buluntuların bilimsel çalışmalarının yapılarak tanım ve tasniflerinin yapılmasıdır. Bunların yanında hali hazırda bilinen yerleşmelerin güncel durumlarının belgelenerek dijital ortama aktarılması da yapılacaktır. Bu maksatla yapılan çalışmalarda aşağıda verilen bulgulara ulaşılmış, tespitler yapılmıştır.

\section{Seydişehir ilçesinde yapılan araştırmalar}

\section{Seydişehir Höyük II}

Seydişehir Höyük II, Seydişehir İlçe Merkezinde, Seydişehir organize sanayinin arkasında konumlanmaktadır (Şekil 3). Höyük 1996 yılı çalışmalarında Hasan Bahar tarafından tespit edilmiştir. Bu dönem çalışmalarında höyüğün II. bin yıldan Klasik Dönemlere kadar yerleşim gördüğü bildirilmiştir (Bahar, 1999a, s. 1). Ancak burada en çok göze çarpan buluntular Demir Çağına tarihlenen krem astar üzerine kahverengi boya ile yapılmış konsantrik dairelerin olduğu geometrik bezemeli kap parçalardır (Bahar, 1999a, s. 3). 2020 çalışmalarında höyügün etrafında bulunan arazilerden başlanarak, höyük en üst noktasına kadar incelenmiş olup höyügün çevresinde ve höyük yüzeyinde yapılan çalışmada Demir Çağı ve Roma Dönemine tarihlenebilen seramikler tespit edilmiştir. Bu parçalar arasında krem astar üzerine kahverengi boya ile bezenmiş, meander motifli, olasılıkla bir boyunlu çömlek veya kraterin omuzdan boyun kısmına geçiş parçası dikkat çekicidir (Şekil 3a). Parça kalın cidarlı, kaba formlu olup hamuru ince kumlu, kireç, mika ve taşcık katkılıdır. Parça üzerindeki meander motif süslemenin benzerleri Konya/Alaaddin Tepesi Höyükte de ele geçmiştir (Bahar, 1999b, s. 55, 58 Lev. VI, X) Boğazköy kazılarında 
açığa çıkarılan bazı kaplar üzerinde Orta Demir Çağı'na tarihlenen meander motifli örnekler bulunmaktadır (Bossert, 2000; Tafel 105, 113). Benzer boya bezemeli örneklerden yola çıkarak bu parçanın Orta Demir Çağı veya Geç Demir Çağı'na tarihlenmesi uygun olacaktır.

\section{Suberde Höyük}

2020 yılı yüzey araştırması kapsamında incelenen Suberde Höyük, Seydişehir İlçesinin yaklaşık $11 \mathrm{~km}$ güneydoğusunda, Suğla Gölü'nün kuzeybatı kıyısında yer alan Gölyüzü (eski adı Suberde) köyünün girişinde yer almaktadır. İlk kez Beyşehir-Suğla Gölleri Yüzey Araştırması kapsamında 1963 yılında Ralph Solecki tarafından tespit edilen höyükte (Solecki, 1965, s. 133) Jacques Bordaz başkanlığında 1964-65 yıllarında kazılar yapılmıştır (Bordaz, 1973, s. 283). İki sezon devam eden kazılarda Prehistorik Dönemlere tarihlenen 3 kültür tabakası tespit edilmiştir. Bunlardan en üst tabaka geç dönem mezarları ile bozulmuştur. Sonraki iki katman Prehistorik Döneme tarihlenir (Bordaz, 1969, s. 44 - 46). Yerleşmenin mimari yapı geleneği tam olarak açığa çıarılamamakla birlikte, kısmen sağlam korunagelmiş kerpiç duvarları olan bir birine bitişik düzende yapılmış bazı yapı kalıntılarından dörtgen veya kare planlı bir mimari yapı geleneğinin olduğu anlaşılmaktadır (Bordaz, 1969, s. 44-46, 63). Çalışmalarda çanak-çömlek buluntuların açığa çıkarıldığı bilinmekle birlikte buluntular hakkında kazı raporlarında ayrıntılı bilgiye yer verilmemiştir. Elde edilen bilgilere göre III. tabakanın üst kısımlarında 8 adet; karışık buluntu veren I. tabakadan ise 12 adet Neolitik Döneme tarihlenebilecek pişmiş toprak kap parçaları tespit edilmiştir (Bordaz, 1969, s. 51). Serap Özdöl tarafından 2006 yılında tamamlanan doktora tezi kapsamında Suberde seramik buluntuları Çatalhöyük ve Erbaba'nın da yer aldığı Neolitik Dönem yerleşmelerinin seramikleri ile ayrıntılı olarak çalışılmıştır (Özdöl, 2006). 2020 yılı araştırmaları kapsamında inceleme yaptığımız Suberde Höyük'ün büyük bir kısmı ağaçlandırılmış ve mezarlık olarak kullanıldığı görülmüştür. Höyüğün üzerindeki bu tahribattan Suberde Höyük'te Prehistorik Dönem yerleşmesine dair bir iz görülmemektedir. Suberde de tarafımızca yapılan yüzey araştırmalarında herhangi bir pişmiş toprak çanakçömlek parçasına ve/veya obsidiyen'e rastlanmamıştır. Höyüğün oturduğu alan dışında olasılıkla Neolitik Döneme tarihlenebilecek bir taş balta ele geçmiştir(Şekil 4).

\section{Eski Köytepe Höyük}

Eski Köytepe Höyük Seydişehir İlçesi, Kesecik Mahallesi sınırları içerisinde Suberde Höyük'e çok yakın bir mesafede yer almaktadır. Höyük 1963 yılında Ralph Solecki tarafından Beyşehir-Suğla Gölleri Yüzey Araştırması kapsamında tespit edilmiştir (Solecki, 1965, s. 141). Solecki çalışma yapılan alanların listesi içinde yeni tespit edilen yerleşme olarak yer verdiği Eski Köytepe yerleşmesinin hangi döneme tarihlendiği veya ele geçen buluntularla ilgili hiçbir bilgi verilmemektedir. Solecki ve/veya Bordaz'ın daha sonra yaptığı çalışmalarında da höyük ile ilgili herhangi bir bilgi bulunmamaktadır. 2020 yılı yüzey araştırması bünyesinde tarafımızca ayrıntılı çalışılan höyükte önemli bulgular tespit edilmiştir. Suberde Höyük'e çok yakın bir mesafede konumlanan Eski Köytepe Höyük Suğla Gölü su toplama alanına yaklaşık $2 \mathrm{~km}$ mesafede bulunmaktadır. Eski Köytepe Höyük'ün eteklerinin kısmen tarım arazisi olarak kullanıldığı görülmüştür. Höyüğün üst kısımlarının tamamını, yer yer yaklaşık 1-1.5 m uzunluğundaki yabani bitkilerle kaplamıştır (Şekil 5). Bu bitki yoğunluğundan dolayı höyüğün bu kısımları istenilen düzeyde araştırılamamıştır. Ancak höyüğün güneybatı kesiminde, defineciler tarafından açılan kaçak kazı alanında bir havan eli ve pişmiş toprak kap parçaları tespit edilmiştir (Şekil 6). Form ve yüzey özellikleri dikkate alınarak yapılan ön değerlendirmede pişmiş toprak parçaların Geç Neolitik / Erken

SEFAD, 2021; (46): 215-236 
Kalkolitik Döneme tarihlenebilecekleri anlaşılmıştır. Ele geçen parçaların tamamı el yapımıdır. Bunların ince kumlu kil hamurlarında gözle görülebilecek büyüklükte kireç, mika, taşcık gibi inorganik katkı yanında kaba organik katkının varlığı da görülmüştür. Burada değerlendirilen 5 parçanın 3'ü basit dik yükselen ağızlı, bir tanesi içe kapanan ağızlı, bir tanesi de dışa çekik ağızlıdır. Bunlardan kırmızımsı kahverengi bir örnek dışında kalanların tamamı koyu yüzlü örneklerden oluşmaktadır. Burada ele geçen havan eli (Şekil 6) küçük boyutlu olmasıyla diğer yerleşmeler ele geçen örneklerden farklıdır. Bu örnek bilinen havan elleri dışında olasılıkla daha ayrıntılı ve/veya özenli ezilecek nesneler için kullanılmış olabilir. Genel ile Ele geçen pişmiş toprak kap parçalarından bir değerlendirme yapıldığında höyüğün en erken Seramikli Neolitik Dönemde iskan görmüş olduğu düşünülmektedir.

\section{Kesecik Höyük}

Höyük adından da anlaşılacağı gibi, Seydişehir İlçesi, Kesecik Mahallesi sınırları içerisinde yer almaktadır. 2020 yılı çalışmalarında Kesecik Höyük'ün tamamının ağaçlandırıldığı ve büyük bir kısmının mezarlık alanı olarak kullanılmış olduğu görülmüştür. Höyük üzerinde yapılan incelemelerde çok sayıda pişmiş toprak kap parçası tespit edilmiştir. Parçalar arasında Kalkolitik ve Tunç Çağ 1 birkaç örnekle temsil edilirken (Şekil 7) buluntuların büyük çoğunluğu Demir Çağından Roma Dönemine kadar uzanan geniş bir aralığı yansıtmaktadır. Burada ele geçen Kalkolitik Döneme tarihlenen üç parça kaba el yapımı olup kahverengi ve kırmızı yüzeylidir. İnce kum katkılı kil içinde kireç, küçük taşçık ve mika da bulunmaktadır. Tunç Çağına tarihlenen örnekler ise daha çok kırmızımsı açık kahverengi astarlı olup mika, taşcık ve kireç katkılıdır. Demir Çağı örnekleri genelde koyu yüzlü (gri, siyah), çark yapımı kaba mallardan (coarse ware) oluşmaktadır. Kil katkıları incelendiğinde kilin özensiz hazırlandığı içeriğindeki iri taşcık, kireç, mika ve bitkisel katkılardan anlaşılmaktadır. Kesecik Höyükte tespit edilen örnekler, yakın çevresindeki yerleşmelerden Seydişehir Höyük II, Göktürk Höyük, Gökhöyük Bağları Höyük, Gemili (Bağra) Höyük ve Ortakaraviran Höyükler'den bilinmektedir (Bahar, 1999b). Bu kapsamda değerlendirildiğinde Kesecik Köyükte tespit edilen Demir Çağı seramiklerinin Suğla Gölü Çevresindeki yerleşmelerde görülen tipik Demir Çağı seramiklerin özelliklerini yansıttığı anlaşılmaktadır.

\section{Göktürk Höyük}

Göktürk Höyük, Seydişehir İlçesi, Kesecik Mahallesi sınırları içerisinde yer almaktadır. Höyük 2020 yılı Suğla Gölü Çevresi Prehistorik Dönem Yüzey Araştırması çalışmalarında tespit edilmiştir. Kesecik Höyük'e çok yakın bir mesafede yer almaktadır. Höyük, batı kısmında güney kuzey yönlü açılan sulama kanallar ile ağır tahribata uğramıştır. Bu tahribat alanında ve höyügün sağlam kalan kısmında çok sayıda çömlek parçası tespit edilmiştir (Şekil 8). Bu parçalar arasında Prehistorik Döneme tarihlenebilecek (Geç Neolitik, Kalkolitik, Tunç Çağı) örnekler yanında Demir Çağı ve sonrasına tarihlenen örneklerde bulunmaktadır. Erken örneklerin tamamı elde üretilmiş olup kil hamur katkısı içinde belirgin mika, taşcık ve kireç bulunmaktadır. Yoğun olmamakla birlikte bitkisel katkıda söz konusudur. Ele geçen parçaların çoğunluğunun özensiz, günlük kullanıma uygun kaba mallardan oluşması, yerleşmenin kapladığı alanın küşük ve yüksekliğinin ova düzleminden yalnız 1.5 metre kadar olması burasının küçük boyutlu bir yerleşme olabileceğini akla getirmektedir. Yerleşmede ele geçen parçalar arasında dikkat çekici erken örneklerden biri de Geç Neolitik, Erken kalkolitik Dönemde yaygın kullanımı bilinen 
(Chesepot) süzgeç kap (Şekil 9) parçasıdır (Salque, vd. 2013, s. 522-525; Takaoğlu, 2006, s. 44). Bir başka dikkat çekici örnek ise kaideden karın seviyesine kadar kısmen sağlam olan ve karın kısmında akıtacak bulunan yayık kap parçasıdır (Gündüz, 2020a şekil 8-8a). Bu kap formunun Kalkolitik Döneme tarihlenen benzer örnekleri Yarıkkaya (Schoop 1998, s. 28) ve Çamlı Bel Tarlası (Schoop, 2017, s. 1-19) yerleşmelerinden bilinmektedir. Schoop, bu kapların Prehistorik Dönemlerde tereyağı elde etmek için yayık yayma kabı (yayık kap) olduklarını bildirmektedir (Schoop, 1998; Schoop, 2017). Göktürk Höyükte tespit edilen yayık ve süzgeç kap parçasının evcilleştirilen hayvanlardan Kalkolitik dönemde ikincil ürün olarak karkas et dışında süt ve süt ürünleri (tereyağı, peynir vb.) elde edilmeye başladığını işaret etmesi açısından önemlidir. Bunun yanında Benjamin S. Arbuckle'nin "Caprıne Exploitation At Erbaba Höyük: A Pottery Neolithic Village In Central Anatolia" başlıklı makalesi BeyşehirSeydişehir civarında Koyun ve Keçi yetiştiriciliğinin Neolitik Döneme kadar uzandığını göstermektedir (Arbuckle, 2008, 345 - 366). Alanda ele geçen Kalkolitik ve Tunç Çağına tarihlenebilecek örneklerin ise daha nitelikli mallardan oluştuğu anlaşılmaktadır. Bunlar koyu kırmızı astarlı, parlak açkılı olmaları ile dikkat çekmektedir. Kırmızı yüzlü parçalar arasında küçük formlu çanaklar bulunmaktadır. Bunların dışında kalan bazı parçalardan bu dönemde daha büyük formlu, kalın cidarlı çömleklerin de var olduğu anlaşılmaktadır. Bu tür kaplar Gökhöyük Bağları Höyük Kalkolitik ve Tunç Çağı malları ile benzerdir. Göktürk Höyük'te tespit edilen Tunç Çağına tarihlenen çanak parçaları Mellaart'ın Çarşamba, Seydişehir, Beyşehir bölgesi için karakteristik olarak belirttiği (Red burnished bowls) kırmızı açkılı mallara benzemektedir (Mellaart, 1963, s. 214). Ele geçen Demir Çağı seramikleri içerisinde günlük kullanıma uygun kaba pişirme kapları yanında büyük depolama kap parçaları da bulunmaktadır. Bunların tamamı mika, taşcık ve kireç katkılıdır. Erken ve/veya Orta Demir Çağı kaba malları yanında bir adet Geç Demir Çağı için karakteristik olan kahverengi boya bezemeli boyunlu çömlek parçası (Şekil 9) yerleşmede iskânın Demir Çağı sonuna kadar devam etmiş olabileceğini düşündürmektedir (Bahar, 1999b, s. 55, 58 Lev. I $X X X)$. Söz konusu pişmiş toprak parçalar üzerinden bir ön değerlendirme yapıldığında, Göktürk Höyük'te olasılıkla Geç Neolitik, Erken Kalkolitik Döneme bir topluluğun yaşadığı, yerleşmedeki iskanın en son Demir Çağında sona erdiği düşünülmektedir.

\section{Süzeklik Höyük}

Süzeklik Höyük Seydişehir İlçesi, Kesecik Mahallesi sınırları içerisinde yer almaktadır. Gökhöyük merkezde bulunan Gökhöyük, Suberde ve Göktürk Höyük'e yaklaşık 2-3 km mesafede bulunmaktadır. Suğla Gölünün sularının çekilmesiyle oluşan düzlükte yükselen höyügün tamamı tarım arazisi olarak kullanılmaktadır. Sürekli tarım faaliyetlerine maruz kalan höyügün yüzeyinde nitelikli bir esere rastlanmamıştır. Tespit edilen eserler arasında Geç Demir Çağından Roma Çağına kadar farklı dönemlere ait amorf çanak-çömlek parçaları bulunmaktadır. Bunlar dışında Demir Çağı özellikleri yansıtan küçük bir (amorf) pişmiş toprak yayık parçası, höyükteki Demir Çağı iskanını desteklemesi açısından önemlidir. Ayrıca bu parça bölgede yayık kap parçaları tespit edilen Gökhöyük Bağları Höyük (Gündüz, 2020c), yanı sıra bu çalışmada yer verilen Gemili ve Ortakaraviran Küçük Höyük ile olası ilişkiler hakkında fikir vermesi bakımından da önem taşımaktadır. 


\section{Gemili (Bağra) Höyük}

Höyük Seydişehir İlçesi, Kumluca Mahallesi sınırları içerisinde yer almaktadır. Solecki tarafından 1963 yılı çalışmalarında ziyaret edilmiştir (Solecki, 1965, s. 141). Solecki birçok yerleşmede olduğu gibi bura ile ilgili de ayrıntılı bilgi vermezken çalışmalar kapsamında incelediği yerleşmelerin listesinde Gemili Bağra Höyük'te bulunmaktadır (Solecki, 1965, s. 141) 2020 yılı araştırmaları kapsamında tarafımızdan Gemili (Bağra) Höyük yüzeyinde ayrıntılı incelemeler yapılmıştır. Yaklaşık olarak Suğla Gölüne 1 km, Gökhöyük Bağları Höyük'e 3 km mesafede olan yerleşme Seydişehir - Bozkır karayolunun güney batısında yer almaktadır (Şekil 10). Yapılan çalışmalarda çok sayıda pişmiş toprak eser ile birlikte bir adet Bronz Sikke bulunmuştur. Sikke'nin üzeri yoğun patena ile kaplı olduğundan dönemi anlaşılamamıştır. Buluntular arasında Geç Neolitik ve/veya Erken Kalkolitik Döneme tarihlenebilecek bir figürün dikkat çekicidir. Kalkolitik Döneme tarihlenebilecek bir kaç kap parçası yanı sıra yoğun olarak Tunç Çağı seramik parçaları (Bahar ve Koçak 2004, Çizim 24 26) ve Tunç Çağında yoğun kullanımı bilinen hilal, disk ve köşeli ağırlıklar tespit edilmiştir (Şekil 11). Bunların dışında yerleşmede Demir Çağına tarihlenebilecek pişmiş toprak eserler de tespit edilmiştir (Şekil 11). Burada ele geçen parçalar, dışa doğru açlarak yükselen formlu, kalınlaştırılmış dudaklı, geniş ağızlı, kalın cidarlı, kil bünyesinde büyük boyutlu taşcık, mika, kireç ve bitkisel katkı barındıran kaba çanak parçalarıdır. Erken veya Orta Demir Çağına tarihlenen bu çanakların benzerleri Gökhöyük Bağları Höyük'ten (Gündüz, 2019, s. 204 - 222) Ortakaraviran Büyük Höyükten de bilinmektedir. Bölge için karakteristik bir form olan bu kaba çanaklar çark yapımı olup genelde gri ve/veya siyahın farklı tonlarında koyu yüzlü, kaplardır. Demir Çağı seramik parçaları içerisinde dikkat çeken bir adet pişmiş toprak yayık parçası (Şekil 12), Orta Anadolu'da tespit edilen Demir Çağına tarihlenebilecek ilk yatay yayık parçası olma özelliğini taşımaktadır. Bu döneme kadar bilinen yatay yayık kap örnekleri Kalkolitik Dönem (Gündüz, 2020c, s. 329; Şekil 11) ve Tunç Çağı ile sinırlyyken (Cultraro, 2013, s. 157-189; Morris, 2013, s. 70-79; Morris, 2014, s. 205-222; Takaoğlu, 2006, s. 23-44), Demir Çağı örnekleri ise bilinmemekteydi. Koyu yüzlü, kaba formlu bu parçanın iç kısmında yayıklarda bulunan eklentiler hem Gökhöyük Bağları Höyükte (Gündüz, 2020, s. 333) hem de aşağıda verilen Ortakaraviran Küçük Höyükte ele geçen örneklerde de görülmektedir. Bu eklentilerin Suğla Gölü çevresindeki yerleşmelerde ele geçen Demir Çağı yayıkları için karakteristik bir özellik olduğu anlaşılmıştır. Gemili (Bağra) Höyükte tespit edilen bu parça ışığında Orta Anadolu'nun Güneyinde, Suğla Gölü çevresinde Demir Çağında yatay yayık kabın kullanılmış olduğu söylenebilir. Ayrıca ileride bu parçalar üzerinde yapılacak ayrıntılı analiz çalışmaları yayık kapların bölgede bir atölyeden mi yayıldığı yoksa her yerleşmenin kendi yayık kabını mı ürettiği gibi soruların cevaplanmasına katkı sağlayacaktır. Yukarıda verilen ve bölge için karakteristik özellik taşıyan kaba formlu çanak parçaları, boya bezemeli Demir Çağı seramikleri ile diğer yerleşmelerde de ele geçen yayık parçaları Demir Çağında bölgede ortak kültürel ve/veya ticari ilişkilerle desteklenen homojen bir kültürün var olduğunu düşündürmektedir. Höyüğün geç dönemleri hakkında bilgi veren Helenistik ve Roma Dönemi çanak çömlek parçaları da bulunmuştur. Genel bir değerlendirme yapıldığında Gemili (Bağra) Höyük sakinlerinin yaklaşık olarak Geç Neolitik Dönemde burada var oldukları ve höyügün Roma Dönemine kadar yerleşim görmüş olduğu tahmin edilmektedir.

\section{Gökhöyük Bağları Höyük (Kanal Höyük)}

Gökhöyük Bağları Höyük Seydişehir ilçe merkeze yaklaşık 8-10 km. mesafede, Suğla Gölü'nün doğusunda, Gökhöyük Mahallesi, Bağlar mevkinde yer almaktadır (Şekil 13). 
Höyük mahallenin ortasından geçen Seydişehir - Bozkır kara yolunun yaklaşık 1.5-2 km. kadar kuzey doğusunda Kuran köyüne ulaşımı sağlayan köprüye yaklaşık olarak 400 metre mesafededir (Gündüz, 2019, s. 207). Gökhöyük Bağları Höyük'ü ilk 1950'li yıllarda bölgede yaptığı yüzey araştırmalarıyla keşfeden James Mellaart'tır. Mellaart tarafından ilk keşfedildiğinde yerleşme, olasılıkla höyüğün doğu ucunda bulunan toprak kanaldan dolayı, Kanal Höyük olarak adlandırılmıştır (Mellaart, 1954, s. 181,183; Mellaart, 1961, s. 161). 1963 yllında bölgede çalışmalar yapan Ralph Solecki yayınlanan çalışma raporunda Gökhöyük Bağları Höyük hakkında ayrıntılı bilgi vermemekle birlikte Çalışma kapsamı içinde inceleme yapılan yerleri verdiği listede burayı (Hüyük Bağları, Üzümlü veya Kanal Höyük olarak) adlandırmıştır (Solecki, 1965, s. 141). Ian Todd' bölgede yaptığı araştırmalarını yayınladığı 1980 tarihli çalışmasında Kanal Höyük hakkında bilgi vermektedir (Todd, 1980, s. 132). 2002 yılında höyüğün doğu kısmında bulunan eski toprak kanalın yerine DSİ yeni bir beton kanal inşası başlatmış ve bu kanal inşası sırasında arkeolojik eserler ortaya çıkınca çalışmalar durdurulmuştur. Höyük'ün I. derece sit alanı olarak tescillenmesi sırasında maalesef bölgede yapılan çalışmalarla ilgili kaynaklar taranmadığı için Mellaart' in Kanal Höyük olarak adlandırdığı daha sonra Solecki (Hüyük Bağları, Üzümlü veya Kanal Höyük olarak) ve Todd'un incelemelerde bulunduğu Kanal Höyük müze uzmanınca Gökhöyük Bağları Höyük olarak adlandırılmıştır. Bundan dolayı daha önce Kanal Höyük olarak literatürde yer alan yerleşme şuan Gök Höyük bağları Höyük adını taşımaktadır. 2002-2005 yılları arasında höyükte Konya Müze Müdürlüğünce kurtarma kazıları yapılmıştır. Kazı raporlarından anlaşıldığı kadarıyla höyükte en erken Neolitik Döneme tarihlenen arkeolojik eserler tespit edilmiştir. Neolitik Dönem'in de burada 4 kültür katı ile temsil edildiği kazı raporlarından anlaşılmaktadır. Bunlardan dördüncüsü en erken evre iken birincisi en üstteki geç evredir. Yerleşmede açığa çıkarılan mimari yapıların, ocak/fırın platform sıvalı duvar ve taban gibi, iç dizayn özellikleri Çatalhöyük ile birbirine çok benzemektedir. Ancak Gökhöyük Bağları Höyükte mimari yapı elamanı olarak kerpiç yanında taş kullanılması Çatalhöyük yerleşmesinden farklıdır. Kurtarma kazıları sırasında yüzlerce arkeolojik eser çıkarılmıştır. Çıkarılan eserler uzun yıllar Konya Arkeoloji Müzesinin müzelerinde muhafaza edilmektedir. Yapılan kazılarda açığa çıkan buluntulardan yerleşmenin Prehistorik Dönem seramik üretim gelenekleri de anlaşılmaktadır. Neolitik Dönem çanak-çömlek buluntular içerisinde kahverengi, devetüyü örneklerin yanı sıra koyu yüzlü, açkı izli, mineral içerikli, basit dik yükselen, içe doğru daralan ağızlı çömlek parçalarının varlığı görülmüş̧ür. Geç Neolitik, Erken Kalkolitik tabakalarda ise çok sayıda S profilli, kısa boyunlu, dışa çekik ağızlı kırmızı astarlı örneklerin varlığı görülmüştür. 2020 yılı yüzey araştırmaları kapsamında Gökhöyük Bağları Höyük'te arkeolojik çalışmalar tekrar başlamıştır. Araştırma kapsamında yüzeyden toplanan eserler kazılarda daha önce açığa çıkan buluntular referans alınarak değerlendirilmiştir. 2020 yılı çalışmalarında ele geçen pişmiş toprak örneklerde kazılardan elde edilen verilerle örtüşmektedir (Şekil 14). Genel olarak değerlendirildiğinde Gökhöyük Bağları Höyüğü Erken Dönem seramiklerinin siyahtan griye ve kırmızımsı kahverengiden devetüyüne değişen renklerde astarlı oldukları anlaşılmıştır. Gökhöyük erken dönem seramikleri Çatalhöyük VIII-VI tabakalar ve Erbaba III. tabaka, ile benzer özellikler yansıtmaktadır. Ayrıca Mellaart Çukurkent seramiklerini değerlendirirken Gökhöyük (Kanal höyük) seramiklerinin Alan Höyük, Çukurkent yerleşmeleri ile benzerliklerini belirtmiştir (Mellaart, 1954, s. 181). Gökhöyük Bağları Höyük'te açığa çıkarılan Geç Neolitik Erken Kalkolitiğe tarihlenebilecek kaplar, aşağıda ayrıntılı bilgilerinin verdiğimiz 2020 yılı yüzey araştırmalarında tespit edilen Balıklava/Karayaka Yerleşmesi ve

SEFAD, 2021; (46): 215-236 
Akkise/Yahyalı yerleşmesinde tespit edilen kırmızımsı yüzlü 'S' profilli kaplar ile benzemektedir. Gökhöyük kırmızı astarlı Geç Neolitik/Erken Kalkolitik Kapları üzerinde bulunan sitilize kulpların benzerleri hem Balıklava/Karayaka yerleşmesinde hem Yahyalı yerleşmesinde, olasılıkla aynı döneme tarihlenebilecek, kaplar üzerinde de görülmektedir.

\section{Ortakaraviran (Büyük) Höyük II}

Höyük Seydişehir İlçesi'nin güneydoğusunda, Aşağıkaraviran Köyü'nün hemen yanında; Seydişehir-Bozkır karayolunun yaklaşık 2 km batısında yer almaktadır (Şekil 15). Suğla Gölünün kıyısında bulunan höyük ilk kez Mellaart tarafından keşfedilmiş daha sonra Ralph Solecki ve Hasan Bahar tarafından da incelenmiştir (Mellaart, 1954, s. 192; Mellaart, 1958, s. 141-142; 1963, s. 209; Solecki, 1965, s. 141; Bahar ve Koçak 2004, s.51, Tablo N). Mellaart höyükte yaptığ1 incelemelerde ETÇ seramikleri tespit etmiştir. Bahar yaptığ1 incelemelerde Kalkolitik ve Tunç Çağı seramikleri bulmuştur. Tarafımızdan 2020 yılı çalışmaları kapsamında höyüğün yüzeyinde yapılan incelemelerde tespit edilen çanakçömlek parçaları arasında Tunç Çağı, Demir Çağı, Hellenistik ve Roma Dönemlerine tarihlenebilecek örnekler belirlenmiştir (Şekil 16). Bunların tamamı çark üretimi kaplardır. Höyükte bulunan Tunç Çağ çanakların benzeri bölgede çeşitli yerleşmelerden bilinmektedir (Bahar ve Koçak 2004, Çizim 24 - 26) En yoğun buluntu gurubunu oluşturan Demir Çağ malları Gökhöyük Bağları Höyük ve yukarıda örnekleri de verilen Gemili (Bağra) Höyük kaba çanaklara benzer parçalar ile temsil edilir. Bunlar bölgenin karakteristik Demir Çağ1 kap form özelliklerini yansıtır (Bahar, 1999b). Demir Çağına tarihlenen örneklerin özensiz hazırlanmış kil hamuru içinde seyrek görülen bitkisel katkıya dışında yoğun kum, taşcık, kireç ve mika gibi inorganik katkı da mevcuttur. Helenistik ve Roma Dönemi seramikleri ise daha özenli yapılmışlardır. Açık formlu çanakların bazılarının ağız kısımlarında bant bezeme bulunmaktadır (Şekil 16). Bunlarda Demir Çağı örneklerde görülen iri katkılar görülmez. Ancak kil yataklarının değişmediği kap yüzeyinde kireç ve mika katkının görülebilmesinden tahmin edilmektedir. Höyügün en üst kısmında taş temelli geç dönem mimari kalıntısı (olasılıkla bir sarnıç ?) görülmüştür. Ortakaraviran Höyük II seramik buluntularının Gökhöyük Bağları Höyük seramikleri yanında bu çalışmada değerlendirilen yerleşmelerle de benzer özellikler yansıttığı anlaşılmıştır.

\section{Ortakaraviran (Küçük) Höyük I}

Yerleşme Seydişehir İlçesi'nin güneydoğusunda, Aşağı Karaviran Köyü'nün hemen yanında, Seydişehir-Bozkır karayolunun güneybatısında yer almaktadır. Höyük ilk kez Mellaart tarafından keşfedilmiş daha sonra Ralph Solecki ve Hasan Bahar tarafından da incelenmiştir (Mellaart, 1963, s. 209; Solecki, 1965, s. 141; Bahar ve Koçak 2004, s. 51; Tablo N). Mellaart höyükte ETÇ II seramikleri tespit etmiştir. 2020 çalışmalarında höyüğün yüzeyini kaplayan yabani bitkilerden saha istenilen düzeyde taranamamıştır (Şekil 17). Bunlara rağmen yapılan incelemelerde Demir Çağı ve Helenistik Döneme tarihlenen pişmiş toprak parçalar tespit edilmiştir. Bunlardan ilki Demir Çağına tarihlenen koyu yüzlü kaba formlu yayık kap parçasıdır (Şekil 18). Kaba formlu kabın kil hamurunda iri taşcık, kum, kireç ve mika gibi inorganik katkılar bulunmaktadır. Bu parçanın içi kısmında da Gökhöyük Bağları Höyük (Gündüz, 2020c, s. 333; Şekil 13,14, 17) ve yukarıda bahsi geçen Gemili (Bağra) Höyük Demir Çağı örneklerinde olduğu gibi eklentiler bulunmaktadır. Yayık kap parçaları bölgede daha önce yalnız Gökhöyük Bağları Höyük'ten örnekler ile biliniyorken Suğla Gölü Çevresi Prehistorik Dönem Yüzey Araştırma Projesi ile bu bölgede farklı yerleşmelerde de tespit edilmişlerdir. Demir Çağına tarihlenen ikinci parça ise ağız 
kenarından tutamak kulplu, tumağında ip deliği bulunan parçadır (Şekil 18). Bir çanağa ait olduğu anlaşılan bu parça bej / krem astarlı olup üzerinde iç içe daire spiral motifleri bulunmaktadır. Bu tür boyalı kap parçaları Hasan Bahar tarafından yapılan çalışmalarda da tespit edilmiştir (Bahar, 1999a, s. 2-6; Bahar-Koçak 2004, s. 29). Seydişehir Höyük II'de ele geçen bu örnekler daha çok Orta Demir Çağı ve/veya Geç Demir Çağına tarihlenmektedir. Bunun dışında Gökhöyük Bağları Höyük Demir Çağı seramik parçaları arasında da benzer boya bezemeli örnekler tespit edilmiştir. Benzerlerinden yola çıarak bu bezemeli kap parçasının da Orta Demir Çağı ve/veya Geç Demir Çağına tarihlenmesi uygun olacaktır.

\section{Ahırlı İlçesinde Yapılan Araştırmalar}

\section{Akkise/Yahyalı Höyük}

Akkise/Yahyalı Höyük, Ahırlı ilçesi, Akkise Mahallesi sınırları içerisinde yer almaktadır. Suğla Gölüne yakın bir mesafede konumlanan yerleşme Suğla Gölünün güney doğu kesiminde yüksek bir yamaçta kurulmuştur (Gündüz, 2020b, s. 245). Yerleşmenin kurulu bulunduğu alanda çok sayıda pişmiş toprak çanak çömlek parçası, obsidiyen, çakmaktaşından alet ve yonga parçaları ile birlikte havan eli ve öğütme taşları tespit edilmiştir. Bunlara ilaveten kaçak kazıcılar tarafından yerleşim yerinde açılan bir çukurda taş temelli bir mimari yapı parçası açığa çıkarılmıştır (Gündüz, 2020b, Figür 2-6). Yahyalı Höyük'te yüzeyde tespit edilen çanak-çömlek parçaları arasında çoğunlukla kırmızımsı, kırmızımsı kahverengi, devetüyü veya kahverenginin farklı tonları yanında siyah ve/veya gri renkte koyu yüzlü açkılı mallarda bulunmaktadır. Kaplar kendi içinde, içe kapanan ağızlı, basit dik yükselen ağızlılar ve dışa çekik ağızlılar olarak farklı gruplara ayrılmıştır (Şekil 20). Akkise/Yahyalı'da ele geçen Koyu yüzlü açkı izli, içe kapanan ağızlı benzer çömlekler (Şekil 21) Yahyalı höyüğe çok yakın mesafede yer alan, Gökhöyük Bağları Höyük ve Çatalhöyük'ten (Özdöl, 2006, Levha 27-40) bilinmektedir. Beyşehir Gölü kıyısında yer alan Erbaba (Özdöl, 2006, Çizim 147-148), Çukurkent, Alan ve Yılan Höyük'te de benzer özelliklere sahip örnekler tespit edilmiştir (Mellaart, 1954, s. 181). Yahyalı'da çoğunluğu oluşturan kırmızı açkılı kapların benzerleri de yine Gökhöyük Bağları Höyüğün Geç Neolitik, Erken Kalkolitik seramikleri arasında görülmektedir. Ayrıca hem Akkise/Yahyalı Höyük'te hem de Gökhöyük Bağları Höyük'te bazı kırmızı yüzlü kapların üzerinde bulunan tutamak kulpların küçülerek sitilize bir hal aldığı görülmektedir. Burada incelenen seramik parçalarının tamamının yüzeyden toplandığı düşünüldüğünde bu parçaların tam olarak tarihlenmesi şuan mümkün değildir. Ancak höyükte ele geçen pişmiş toprak seramik parçaların Geç Neolitik/Erken Kalkolitik Döneme tarihlenen benzer örneklerinden yola çıarak Yahyalı Höyükte Geç Neolitik ve/ya Erkek Kalkolitik Dönemde yerleşik bir kültürün var olduğunu söylemek yanlış olmayacaktır.

\section{Balıklava/Karayaka Höyük}

Yerleşme, Ahırlı ilçesine bağlı Balıklava Mahallesi sınırları içerisinde Karayaka mevkinde yer almaktadır. Alan Suğla Gölü Çevresi Prehistorik Dönem Yüzey Araştırma çalışmaları sırasında tespit edilmiştir. Alanın detaylı incelemesinde yüzeyde Prehistorik Döneme tarihlendirilebilecek pişmiş toprak kap parçaları ile birlikte obsidiyen, çakmaktaşı alet ve yonga parçaları, havan ali, ezgi taşı, çeşitli süs eşyaları tespit edilmiştir. Ele geçen seramik kap parçaları içerisinde yoğunluğu kırmızı astarlı açkı izli mallar oluşturmaktadır. Bunların dışında kalanlar ise gri ve kahverenginin farklı tonlarında mat yüzeyli kaplardır. Tespit edilen parçaların kendi içinde yapılan ilk değerlendirmeye göre kaplar, basit dik yükselen ağızlılar ve $S$ formlular olarak iki farklı form grubuna ayrılmıştır (Şekil 22). Burada 
incelenen örneklerden basit dik yükselen ağızlı örneklerin Akkise Yahyalı ve Gökhöyük Bağları Höyük'te ele geçen kırmızı yüzlü kaplara benzer olduğu anlaşılmıştır. Yukarıda da değinilen, Gökhöyük Bağları Höyük ve Akkise/Yahyalı Höyükte (Şekil 20) kımızı yüzlü bazı kaplar üzerinde bulunan kupların boyutlarının küçülerek stilize bir hal alma geleneği Balıklava/Karayaka Höyükte de görülmektedir (Şekil 22). Bordaz, bölgedeki Seramikli Neolitik Dönem yerleşmesi Erbaba Höyük'te yaptığı kazılarda I. tabakaya ait kırmızı astarlı "S" kıvrımlı seramiklerin form ve yüzey özelliği açısından Hacılar Geç Neolitik (Erken Kalkolitik) IX-VI tabaka kaplarına benzetmiştir (Bordaz - Bordaz, 1982, s. 88). Gözle yapılan ilk incelemelerinde Balıklava/Karaya Mevkinde tespit edilen pişmiş toprak kapların bir kısmının Suğla Gölü havzasında bulunan Gökhöyük Bağları Höyük, Akkise/Yahyalı Höyük ile benzer özellikler yansıttıkları anlaşılmaktadır. Bununla birlikte söz konusu yerleşmelerde ele geçen bu tip kapların hepsinin yaklaşık olarak Geç Neolitik ve/veya Erken Kalkolitik Döneme tarihlenmektedir. Olasılıkla Balıklava/Karayaka Höyükte ele geçen kırmızı astarlı S formlu parçalar da diğer yerleşmeler gibi Geç Neolitik ve/veya Erken Kalkolitik Döneme tarihlenmektedir.

\section{Yalıhüyük İlçesi Araştırmaları}

2020 yılı yüzey araştırmaları kapsamında Yalıhüyük ilçe merkezinde ve Saray Mahallesinde de araştırmalar yapılmıştır. $\mathrm{Bu}$ çalışmalarda Prehistorik Döneme tarihlenebilecek herhangi bir bulguya rastlanmamıştır. Ancak Suğla Gölünün güney kıyısında Yalıhüyük İlçe merkezinde bulunan Yalıhüyük Höyük'teki incelemelerde Helenistik dönemden geç Roma dönemine kadar tarihlenecek seramikler tespit edilmiştir. Bunların dışında höyükte Prehistorik Döneme tarihlenecek herhangi bir bulguya rastlanmamıştır. Höyüğün kapladığı alan ve konumu düşüldüğünde daha erken dönemlere ait verilere ulaşılamaması, höyügünün tarım arazisi olarak kullanılmasından kaynaklı tahribattan olmuş olmalıdır.

\section{SONUÇ}

Suğla Gölü Çevresi Prehistorik Dönem Yüzey Araştırması 2020 yılı çalışma programı doğrultusunda; Konya İli, Seydişehir, Ahırlı ve Yalıhüyük ilçelerinde incelemeler yapılmışır. Bu çalışma kapsamında tespit edilen arkeolojik eserler ve yeni yerleşmeler Suğla Gölü çevresinin Prehistorik Dönemde yoğun yerleşim gördügünü ortaya koymuştur. 2020 yılı yüzey araştırmalarından önce bölgede Prehistorik Döneme tarihlenen yerleşim yeri Suberde ve Gökhöyük Bağları Höyük ile sınırlıydı. Ancak yapılan yüzey araştırmasında tespit edilen eserler bölgede bulunan höyüklerin büyük bir kısmının Prehistorik Dönemde iskan edildiğini göstermiştir. Bu höyüklerden Kesecik Höyük, Göktürk Höyük, Eski Köy Tepe Höyük, Gemili (Bağra) Höyük, Akkise/Yahyalı Höyük ve Balıklava/Karayaka Höyükte tespit edilen Neolitik ve/veya Kalkolitik Dönem buluntuları hem kil içeriği hem form ve yüzey özellikleri açısından benzer özellikler yansıtmaktadır. Gökhöyük Bağları Höyük, Akkise/Yahyalı Höyük gibi yerleşmelerde görülen içe kapanan ağızlı koyu yüzlü, açkı izli malların Beyşehir Gölü kıyısında Erbaba, Alan, Yılan, Çukurkent Höyük'te ve Konya Ovasında/Çatalhöyük'te de bulunmuş olması bölgeler arası da bir ilişki olabileceğini düşündürmektedir. Balıklava/Karaya Mevkiinde tespit edilen kırmızı açkılı $S$ formlu malların Akkise/Yahyalı Höyük, Gökhöyük Bağları Höyük 'te de ele geçmesi bu kapların yayım alanları hakkında bilgi vermektedir. Suğla Gölü çevresinde Prehistorik Dönem buluntularında görülen bu benzerlikler dışında Demir Çağı buluntuları arasında da hem yapısal hem form hem de yüzey özellikleri açısından benzerlik bulunmaktadır $\mathrm{Bu}$ 
yerleşmelerde Demir Çağı seramikleri ile birlikte ele geçen yayık parçaları kültürel ve ekonomik anlamda da ortak özelliklerin olabileceğini akla getirmektedir. Günümüzde Seydişehir ve Beyşehir çevresinde yerel halkın geçim kaynakları arasında olan küçükbaş hayvancılığın Demir Çağda da ekonomik bir değeri olduğu anlaşılmaktadır. Arbuckle'nin bölge ilgili yaptığı zooarkeolojik çalışmalar Beyşehir-Seydişehir Gölü Havzasında Koyun ve Keçi yetiştiriciliğinin Neolitik Döneme kadar uzandığını göstermektedir. Seydişehir/Göktürk Höyük'te ele geçen ve benzerlerinin Kalkolitik Döneme tarihlendiği pişmiş toprak yayık kap parçası ise bu çalışmanın sonuçlarını desteklemektedir. Suğla Gölü çevresinde farklı çalışma alanlarında tespit ettiğimiz, aynı döneme tarihlenen, benzer özelliklere sahip arkeolojik eserler bu yerleşmeler arasında ortak bir kültürün var olduğunu göstermiştir. Daha önce yaptığımız çalışmalarda da üzerinde durduğumuz Suğla havzası içerisinde mikro düzeyde homojen bir kültürün var olabileceği düşüncesi 2020 bulguları ile daha sağlam temellere oturmuştur.

Sonuç olarak yapılan araştırmalardan elde edilen bulgular Suğla Gölü çevresinin Neolitik Dönemden itibaren önemli bir yerleşim bölgesi olduğunu ortaya koymuştur. Demir Çağı ve Helenistik- Roma Dönemi buluntuları ise bölgedeki iskan sürecinin MÖ 1. binin sonuna kadar devam ettiğini göstermektedir.

\section{SUMMARY}

In this study, titled the Prehistoric Period Survey of the Suğla Lake Vicinity in 2020, a preliminary evaluation of the studies carried out in the region is given. The primary aim of the 2020 studies is to contribute to the understanding of the situation of the region in the Prehistoric Period. For this purpose, in the first stage, it was planned to define the settlements in the region, to make an archaeological inventory and to document and record their current status. The survey in line with this program was carried out in the districts of Seydişehir, Konya Province, Gökhüyük, Gölyüzü (Suberde) Kuran, Kumluca, Aşağıkaraören, Ortakaraören and the areas of Akkise, Balıklava and Saray District of Ahırlı overlooking Suğla Lake. Research carried out during the season has shown that the surroundings of Suğla Lake were subject to intense settlement in the Prehistoric Period as it is today. While very few settlements such as Suberde and Gökhöyük Bağları Höyük, which were dated to the Prehistoric Period, were known in the region until this study, the artifacts found in the survey showed that almost all of the mounds in the region were inhabited in the Prehistoric Period. The newly discovered Balıklava / Karaya location between Suğla Lake and Çarşamba Valley entrance shows that the Prehistoric people settled not only around Suğla Lake, but also around Çarşamba Valley, which enables the excess water of Suğla Lake to be transported to Çumra. However, the existence of a line starting from the direction of Beyşehir in the west, continuing from the shore of Suğla Lake and extending over the Çarşamba Valley to the Konya-Karaman Plain became more evident. With the addition of the settlements, we focused on the possibility of these settlements along this route being built on a line that was used as a transition route from west to east or from east to west. In the following years, starting from the settlements around Beyşehir Lake, extensive excavations to be carried out in settlements such as Gökhöyük Bağları Höyük Bağra Höyük Akkise/Yahyalı Höyük around Suğla Lake, and Balıklava/Karayaka Höyük located at the entrance of Çarşamba Valley have the potential to provide important information about the Neolithic process of the corridor called Beyşehir Suğla and/or the initial stages of this period. Due to the similarity of Neolithic Period findings found in the settlements such as Suberde,

SEFAD, 2021; (46): 215-236 
Eski Köy Tepe Höyük, Gökhöyük Bağları Höyük, Bağra Höyük Akkise/Yahyalı Höyük, which were established around the lake at a very close distance from each other, it is estimated that there were micro-level commercial and/or cultural relations between the settlements. With the comprehensive examination of these settlements around Suğla Lake, the Neolithic process and lifestyles of the region, which we think the transition corridor between the southeast and west of Anatolia, will become more understandable.

In addition to the scientific data given above, significant information was obtained about the current status of the mounds. It has been observed that illicit excavations have reached serious and dangerous dimensions in almost all of the examined mounds, destroying the remains. Gökhöyük Bağları Höyük, Bağra Höyük and Yahyalı Höyük, which will shed light on the Prehistoric Period especially around Lake Suğla, are among the mounds that have been mostly destroyed by illegal diggers. In addition to natural factors, it is seen that this destruction by human beings causes a significant loss of data. In order to prevent these destructions and to protect our cultural heritage of thousands of years, intense archaeological studies should be carried out in the region as soon as possible and possible data loss should be prevented.

Makale Bilgileri

Etik Kurul Kararı:

Katılımo Rızası:

Mali Destek:

Çıkar Çatışması:

Telif Haklarn:

Article Information

EthicsCommitteeApproval:

InformedConsent:

Financial Support:

Conflict of Interest:

Copyrights:
Etik Kurul Kararından muaftır.

Katılımcı yoktur.

Bu çalışma Selçuk Üniversitesi, Bilimsel Araştırma Projeleri

Koordinatörlüğü tarafından desteklenen 20401138 numaralı

"Seydişehir İlçesi Prehistorik Dönem Yüzey Araştırma" projesi kapsamında hazırlanmıştır.

Çalışmada kişiler ve kurumlar arası çıkar çatışması bulunmamaktadır.

Çalışmada kullanılan görsellerle ilgili telif hakkı sahiplerinden gerekli izinler alınmıştır.

Exempt from the Ethics Committee Approval.

No participant.

This study was prepared within the scope of "Seydişehir District Prehistoric Period Survey" project numbered 20401138 supported by the Scientific Research Projects Coordination Office of Selçuk University.

No conflict of interest.

The required permissions have been obtained from the copyright holders for the images and photos used in the study. 


\section{KAYNAKÇA}

Arbuckle, S. B. (2008). Caprine Exploitation at Erbaba Höyük: A Pottery Neolithic Village in Central Anatolia. Archaeozoology of the Near East VIII, 345 - 366.

Bahar, H. (1999a). The Konya Region in the Iron Age and its relations with Cilicia. Anatolian Iron Ages 4. Proceedings of the fourth Anatolian Iron Ages Colloquium Held at Mersin, 19-23 May 1997. Anatolian Studies, Vol. 49, 1-10.

Bahar, H. (1999b). Demir Çă̆g'nda Konya ve çevresi. Konya: Selçuk Üniversitesi Yaşatma ve Geliştirme Vakfı Yay.

Bahar, H. \& Koçak, Ö. (2004). Eskiçă̆ Konya araştırmaları 2. Konya: Kömen Yay.

Bordaz, J. (1969). The Suberde excavations, Southwestern Turkey, an interim report. Türk Arkeoloji Dergisi 17-2, 43-71.

Bordaz, J. (1973). Current Research in the Neolithic of South Central Turkey: Suberde, Erbaba and their chronological implications. American Journal of Archaeology, Vol. 77, No. 3, pp. 282-288.

Bordaz, J.\&Bordaz, L. A. (1982). Erbaba. The 1977 and 1978 Seasons in perspective. Türk Arkeoloji Dergisi 26, 85-93.

Bossert, E. M. (2000). Die Keramik Phrygischer Zeit von Boğazköy: Fundeaus den

Grabungskampagnen 1906, 1907, 1911, 1912, 1931-1939 und 1952-1960. Main am Rhein: Von Zabern.

Cultraro, M. (2013). Barrel-Shaped vessels in context: A Long-Range model of dairy production in eastern and central Mediterranean during the late fourth and early third millennia BC., Origini Xxxv, 157-189.

Gündüz, R. (2019). Gökhöyük Bağları Höyük'ünden Erken Demir Çağı seramiği. Karadeniz Uluslararası Bilimsel Dergi, 42, 204-222. doi: 10.17498/kdeniz

Gündüz, R. (2020a). Seydişehir çevresinde tespit edilen yeni yerleşimler. Amisos, 5/9, 362-385.

Gündüz, R. (2020b) Akkise/Yahyalı Höyük: Suğla Gölü kenarında yeni bir prehistorik yerleşim", Arkhaia Anatolika 3, 244-253. DOI: 10.32949/Arkhaia.2020.22.

Gündüz, R. (2020c) Yayık: Gökhöyük Bağları Höyüğünde süt ve süt ürünleri üretimine dair bir ön değerlendirme. Selçuk Üniversitesi Edebiyat Fakültesi Dergisi, 43, 325-344.

Mellaart, J. (1954). Preliminary Report on a survey of Pre-Classical Remains in Southern Turkey. Anatolian Studies, Vol. 4, 175-240.

Mellaart, J. (1961). Early Cultures of the South Anatolian Plateau. Anatolian Studies, Vol. 11, 159-184.

Mellaart, J. (1963). Early Cultures of the South Anatolian Plateau, II: The Late Chalcolithic and Early Bronze Ages in the Konya Plain'. Anatolian Studies, Vol. 13, 199-236.

Morris, S. P. (2013). From Clay to Milk in Mediterranean Prehistory: Tracking a Special Vessel. (Ed.) G. E. Areshia, Celebrating 40 Years of Discovery, 70-79.

Morris, S. P. (2014). Dairy Queen: Churns and milk products in the Aegean Bronze Age. Opuscula, 7, 205-222.

Özdöl, S. (2006). Anadolu'da Erken Dönem çanak çömlek kültürleri ve Çatal Höyük örneği. (Yayınlanmamış Doktora tezi). Ege Üniversitesi, İzmir.

SEFAD, 2021; (46): 215-236 
Salque, M., Bogucki, P. I., Pyzel, J., Sobkowiak-Tabaka, I., Grygiel, R., Szmyt, M., Evershed, R. P. (2013). Earliest evidence for cheese making in the sixth millennium BC in northern Europe. Nature, 493(7433), 522-525. doi: 10.1038/nature11698

Schoop, U.-D. (1998). Anadolu'da Kalkolitik Çağda süt ürünleri üretmi. Bir deneme. Arkeoloji ve Sanat Dergisi, 87, 26-32.

Schoop, U.-D. (2017). Innovation versus beharrung: was macht den unterschied des Hethitischen Reichs im Anatolien des 2. Jahrtausends v. Chr.? (Ed.) A. Schachner. Technologie und innovation im Anatolischen Chalkolithikum. internationaler workshop zu ehren von Jürgen Seeher. 1-19. Istanbul: Ege Yay.

Solecki, R. (1965). An Archeological Reconnaisannce in the Beyşehir-Suğla Area of South Western Turkey. Türk Arkeoloji Dergisi, XIII-1, 129-148.

Takaoğlu, T. (2006). Patterns of dairying in coastal Northwestern Anatolia. (Ed.) T. Takaoğlu. Ethnoarchaeological investigations in Rural Anatolia, 3, 23-44. İstanbul: Ege Yay.

Todd, I. (1980). The Prehistory of Central Anatolia I: The Neolithic Period. Göteborg: Paul Åströms. 


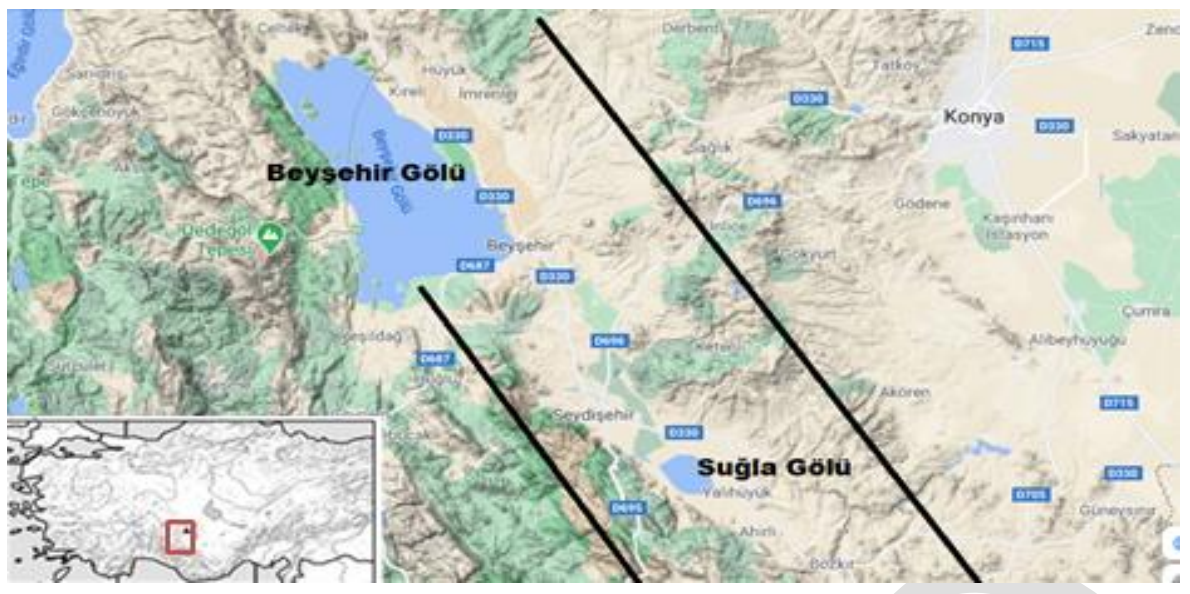

Şekil 1: Beyşehir Suğla Havzası İçerisinde Kalan Alan.

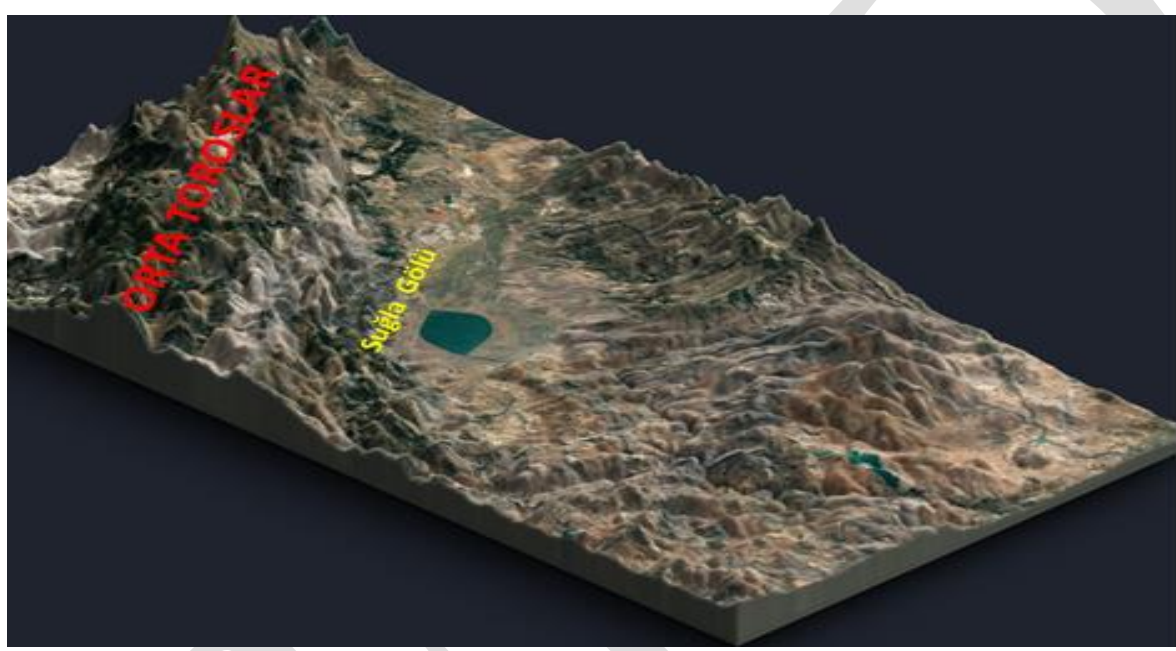

Şekil 2: Suğla Gölü ve Çevresinin Genel Fiziki Durumu.

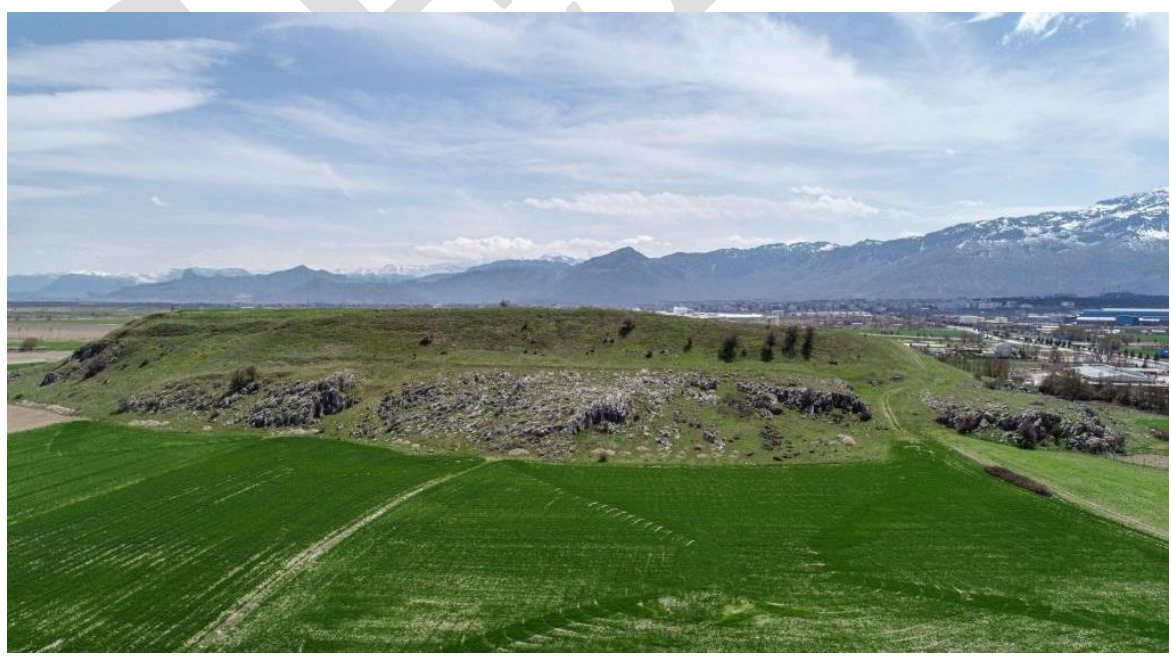

Şekil 3: Seydişehir Höyük II, Havadan Genel Görünüm. 

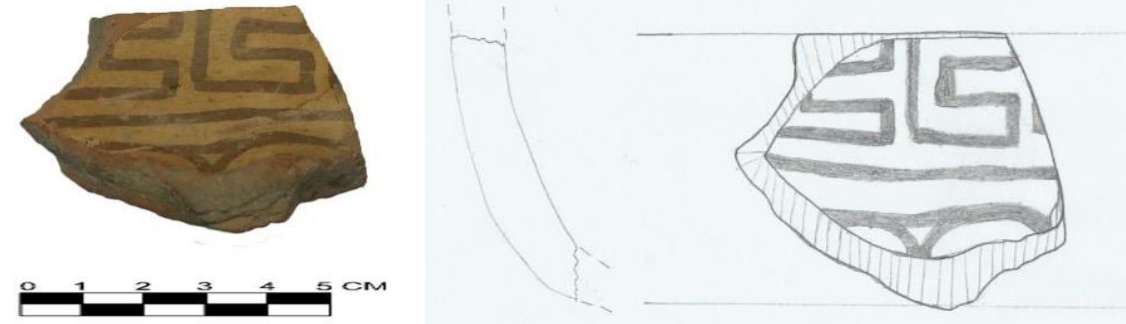

Şekil 3a: Seydişehir II Höyükte Elegeçen Meander Motifli Seramik.
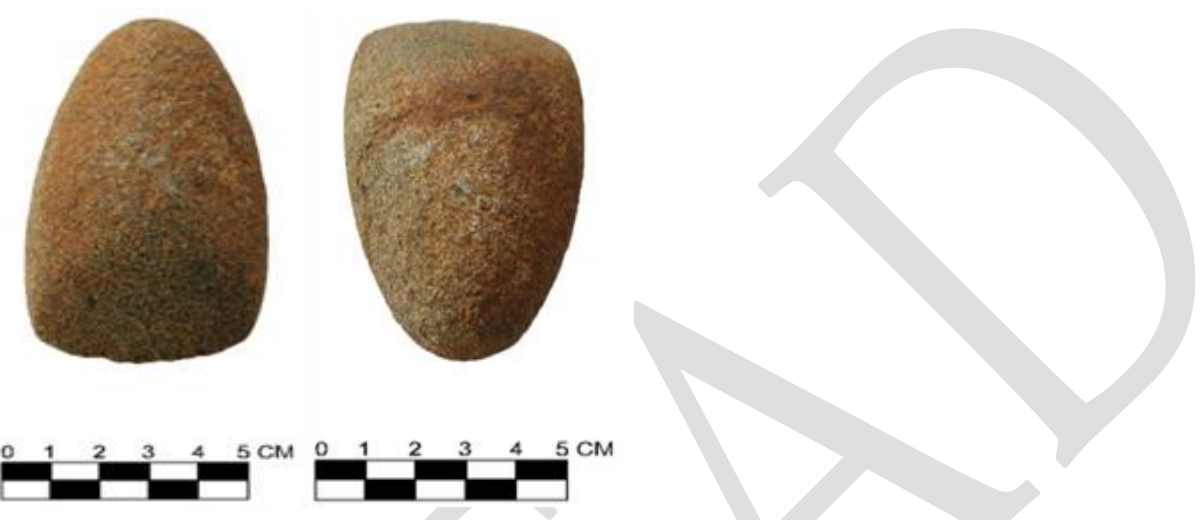

Şekil 4: 2020 Suberde Höyük Çalışmalarında Ele Geçen Taş Balta.



Şekil 5: Eski Köytepe Höyük Havadan Genel ve Detay Görünüm.
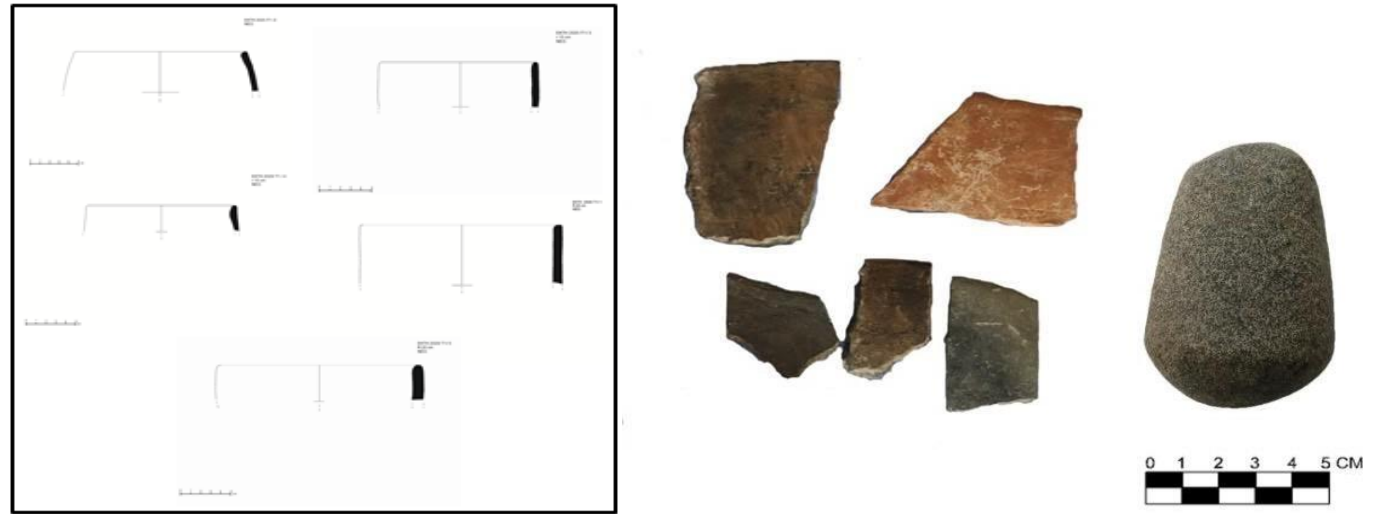

Şekil 6: Eski Köytepe Höyük (Seramik ve Havan Eli) Buluntuları. 




Şekil 7: 2020Yılı Çalışmaları Kesecik Höyük Seramik Buluntuları.



Şekil 8: 2020Yılı Çalışmaları Göktürk Höyük Seramik Buluntuları.
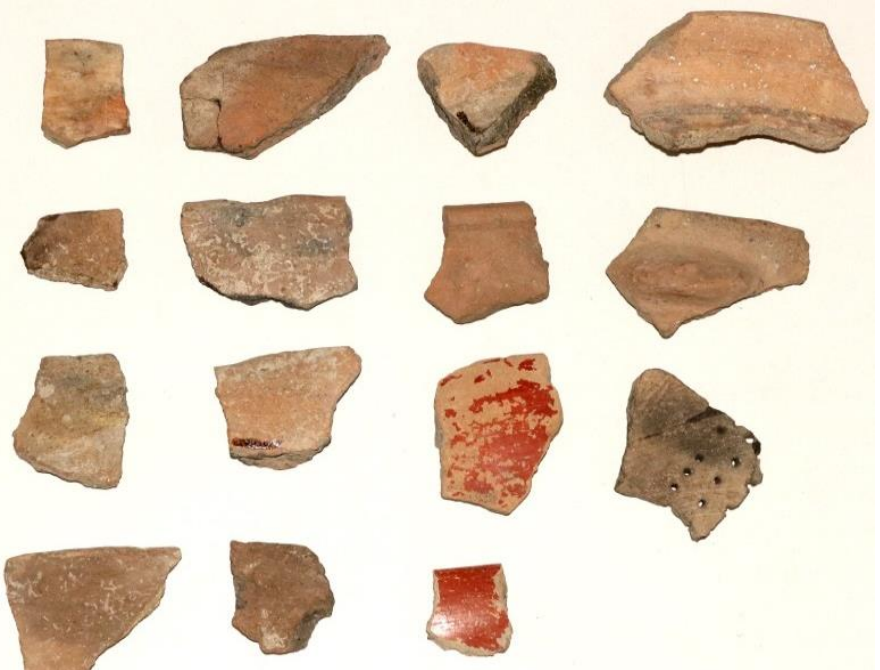

Şekil 9: 2020Yılı Çalışmaları Göktürk Höyük Seramik Buluntuları. 


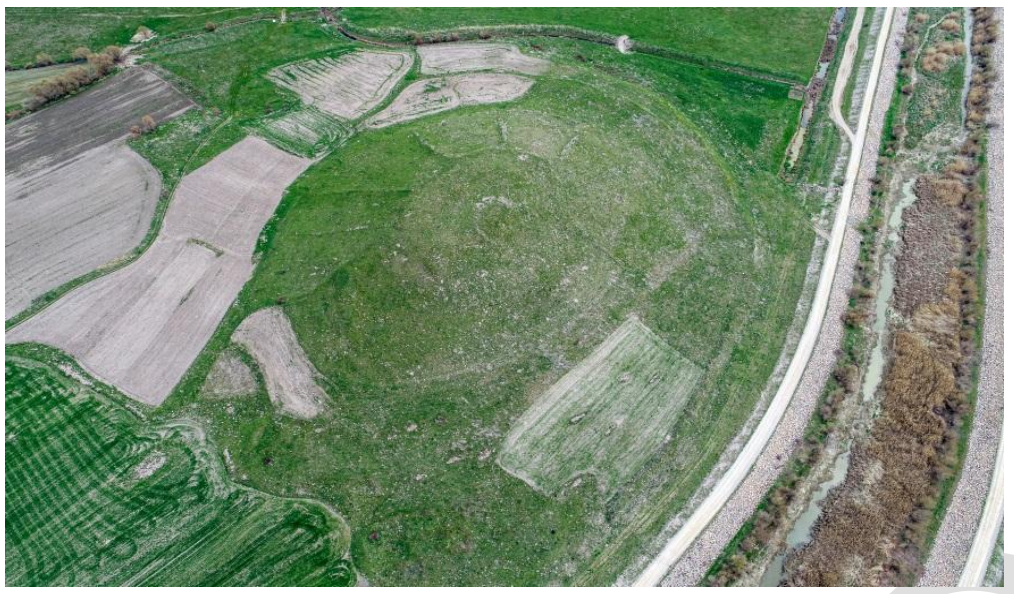

Şekil 10: Gemili (Bağra) Höyük Havadan Genel Görünüm

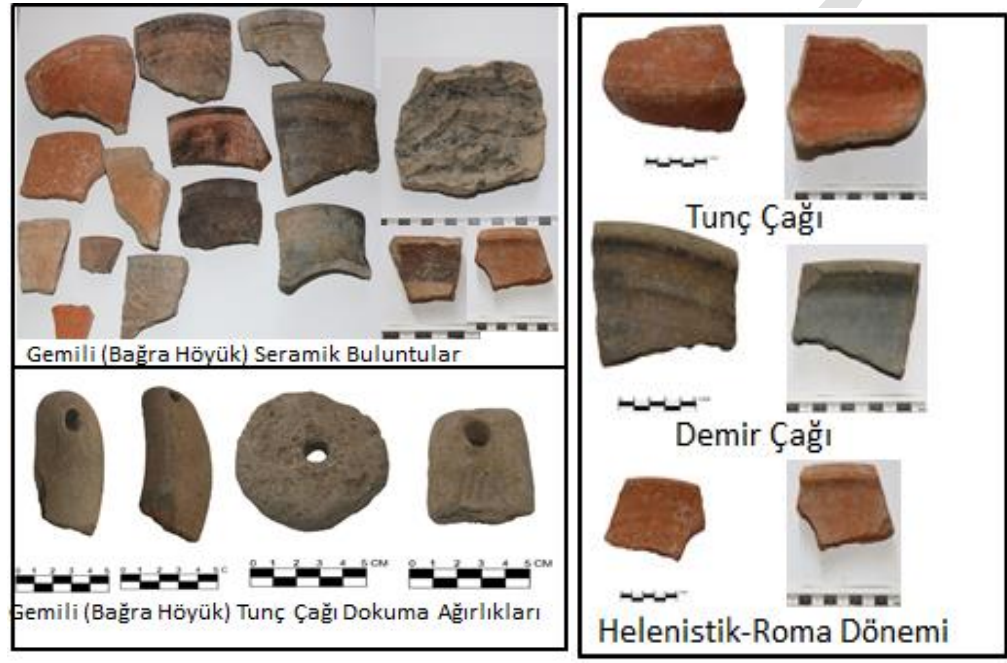

Şekil 11: Gemili (Bağra) Höyük Buluntuları.


Şekil 12: Gemili (Bağra) Höyük Yatay Yayık Kap parçası. 


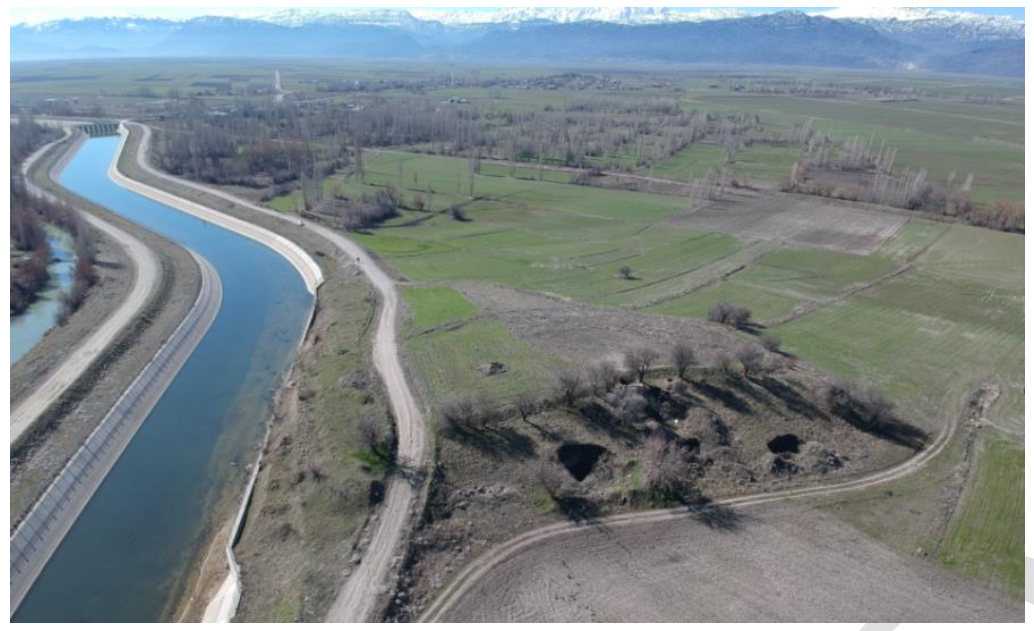

Şekil 13: Gökhöyük Bağları Höyük (Kanal Höyük) Havadan Görünüm.

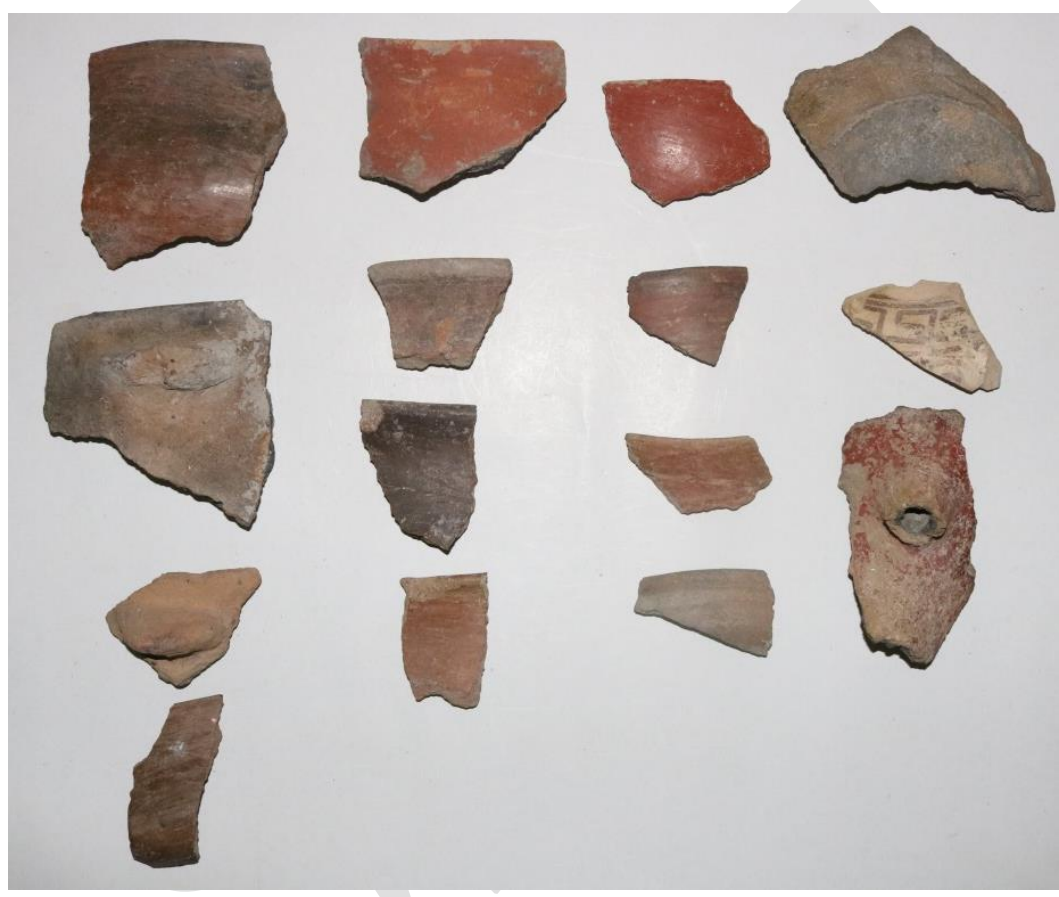

Şekil 14: Gökhöyük Bağları Höyük (Kanal Höyük) Buluntuları. 


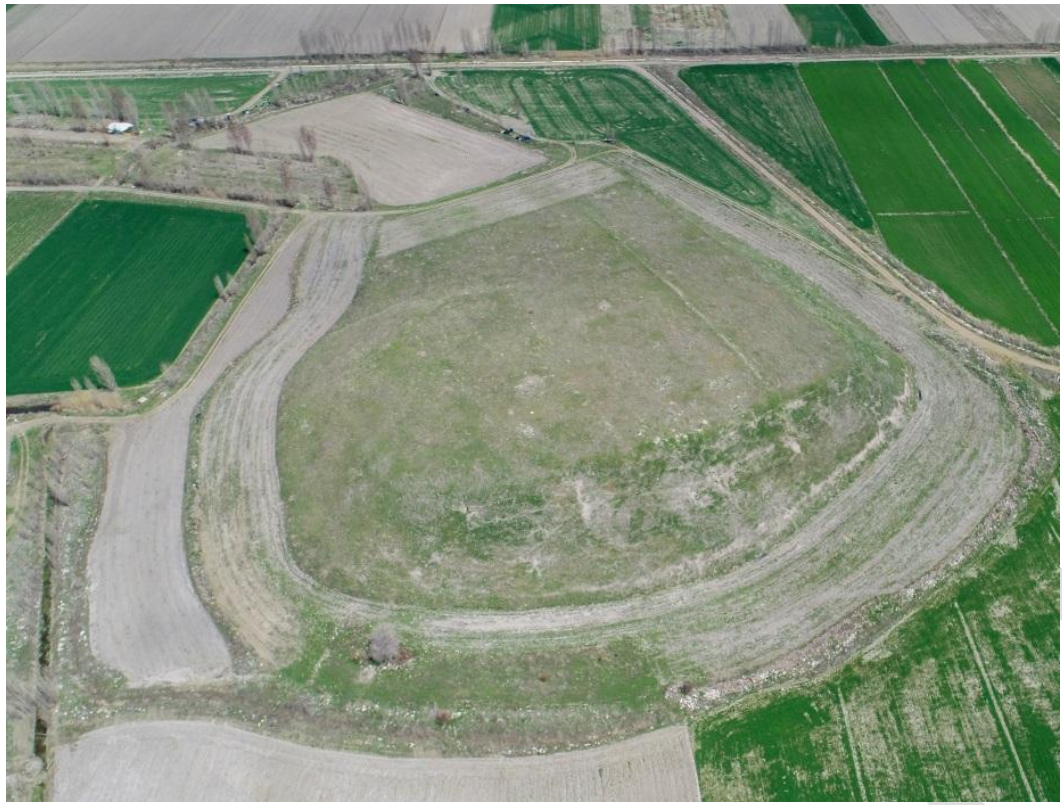

Şekil 15: Ortakaraviran (Büyük) Höyük II Genel Görünüm.

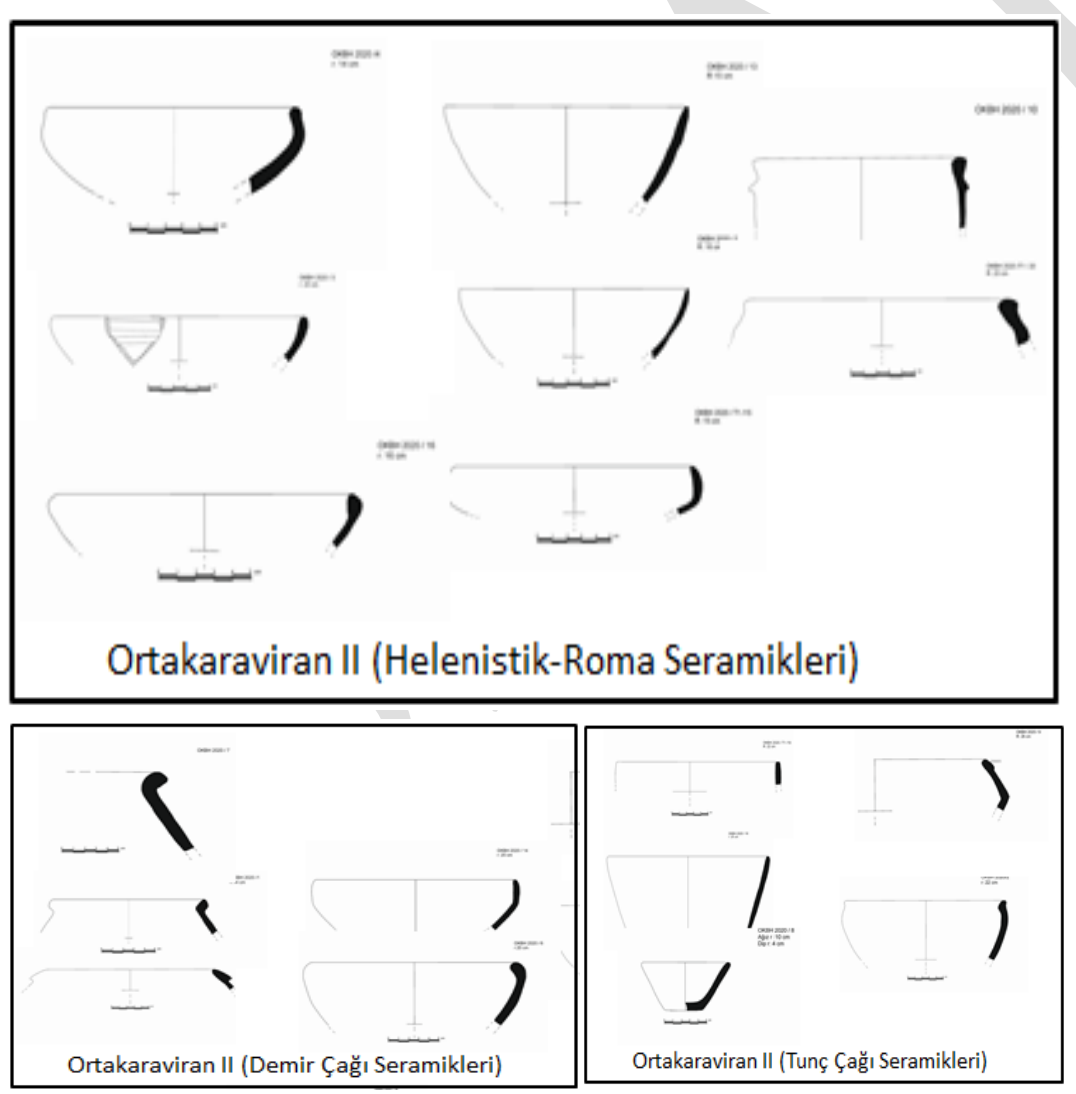

Şekil16: Ortakaraviran (Büyük)Höyük II Kap Formları. 




Şekil 17: Ortakaraviran (Küçük) Höyük I Genel Görünüm.

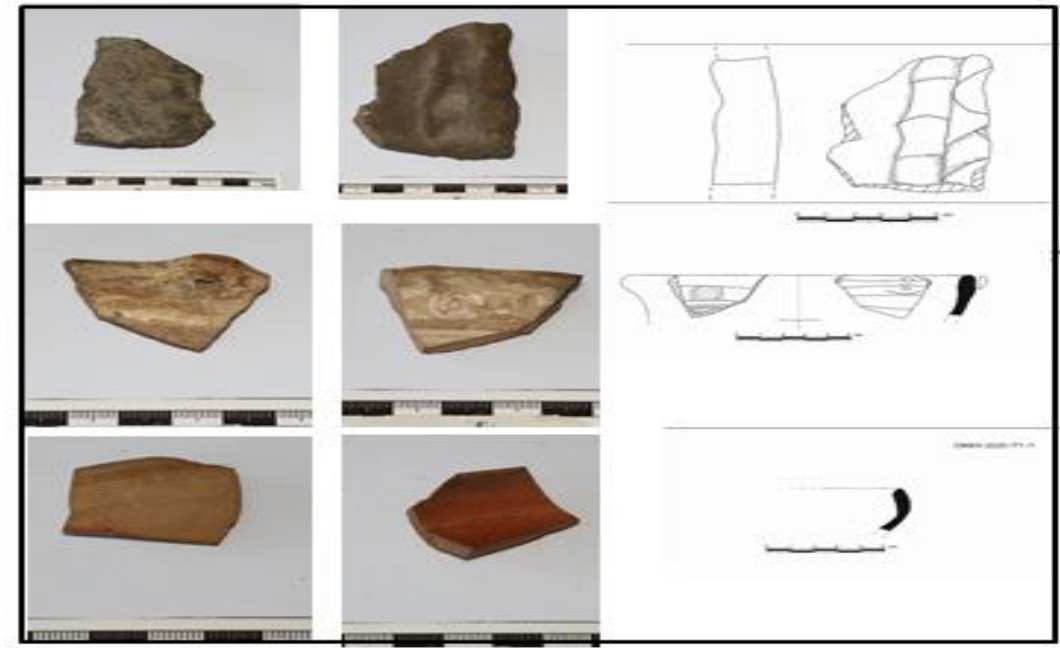

Şekil 18: Ortakaraviran (Küçük) Höyük I Seramik Buluntular.

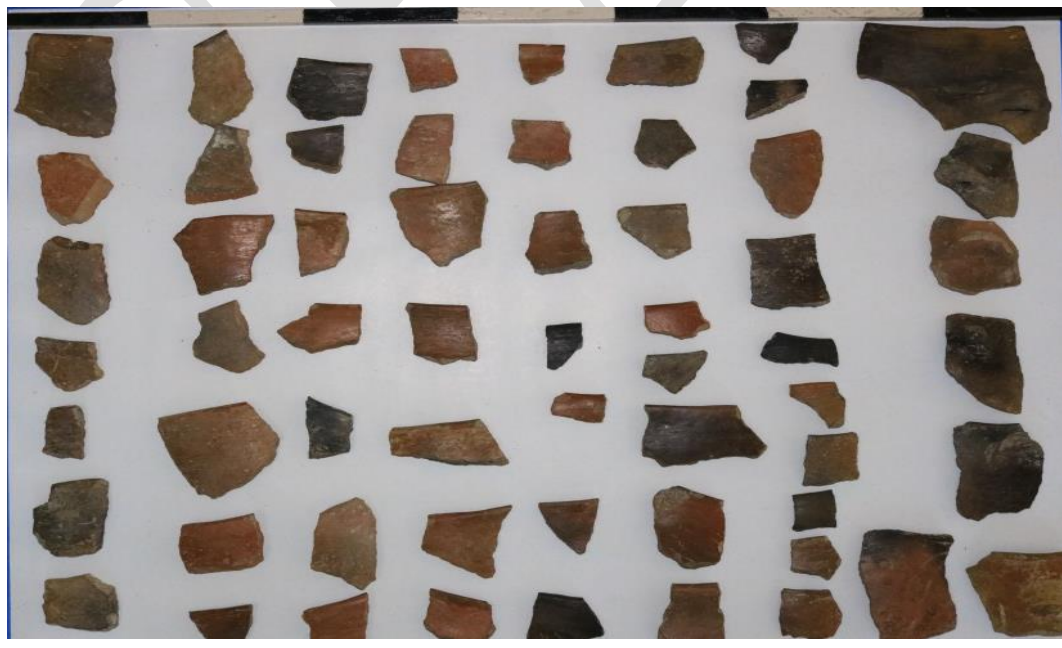

Şekil 19: Akkise/Yahyalı Höyük Seramik Buluntular. 


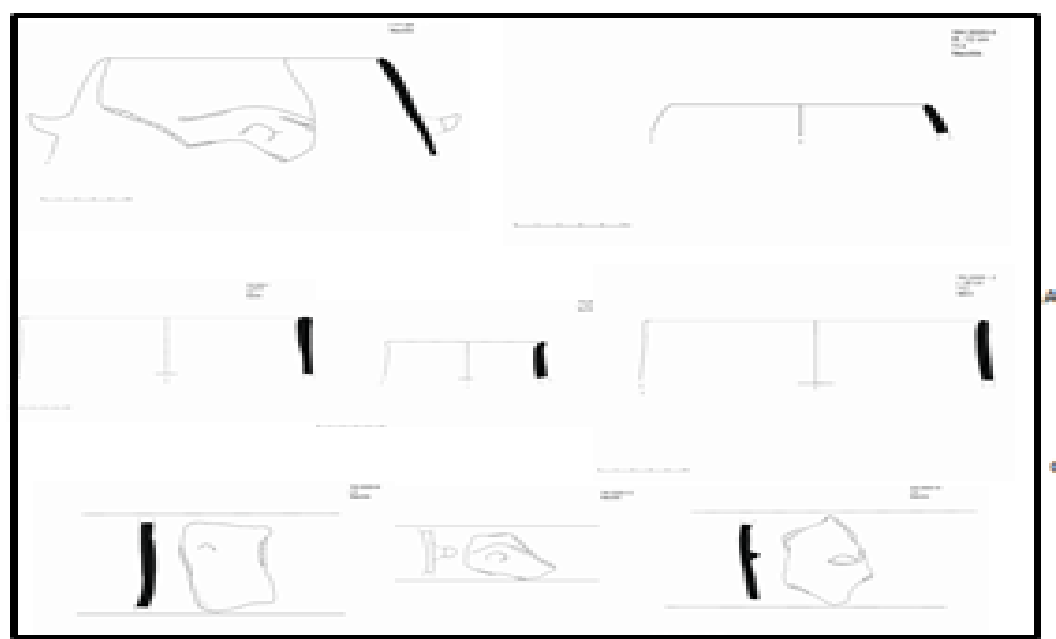

Şekil 20: Akkise/Yahyalı Höyük Kap Formları.



Şekil 21: Koyu Yüzlü, İçe Kapanan Ağızlı Kap Örnekleri.

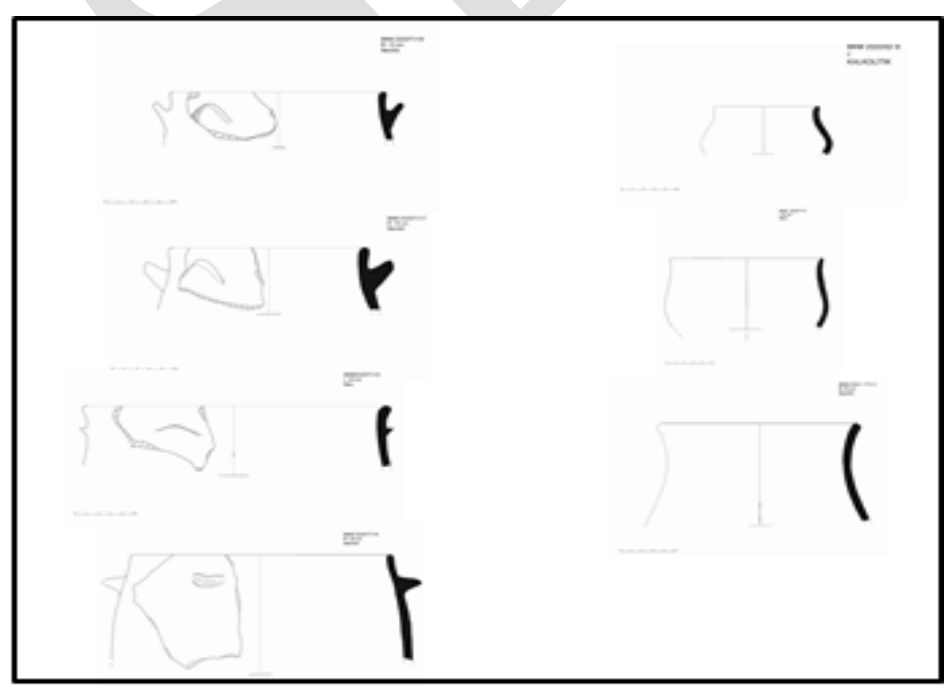

Şekil 22: Balıklava/Karayaka Höyük Kap Formları. 